\title{
PENDIDIKAN PANCASILA, EKSISTENSINYA BAGI MAHASISWA
}

\author{
August Hadiwijono \\ Fakultas Hukum Universitas Merdeka Malang \\ Jl. Terusan Raya Dieng No. 62-64 Malang \\ august.hadiwijono@unmer.ac.id
}

\begin{abstract}
This study attempts to analyze the meaningof Pancasila for students and went to analyze Pancasila's way on campus. The research is normative research. Development and education of Pancasila needs to be done by a college in order to preserve Pancasila values and planting positive values, contained in it for the young generation especially students the student who have important and vital. In addition since Pancasila as an ideology and personality of the country. Pancasila as a view of life nations must be from early introduced and taught to communities Indonesia including college. As forming the intellectual ethical lordship and humanity. The Pancasila personality, must be personality the youth particularly university students who became generation education. Through education of Pancasila, students will be human first, before entering the lecture which learned. Into a citizen of Indonesia who excels in knowledge mastery, but not lost their identity and not drawn from the root culture her people and his faith. In addition it can form personally good in social norms and had good in order to become very good citizens for themselve, others and this people in dailylif. In have values Pancasila in students we can do it in on several, that is an education channel and the organization and message objectively and subjectively. If the values of Pancasila embedded with both in each individual student, will be created Pancasila student who understand norms. Pancasila implementation in life on campus was very important it is for the sake of advance college to campus can produce graduates Pancasila students cannot be built of the people of Indonesia.
\end{abstract}

Keywords: Pancasila, Student, Education.

\begin{abstract}
ABSTRAK
Penelitian ini bertujuan untuk menganalisis makna Pancasila bagi mahasiswa dan untuk menganalisis cara pengamalan Pancasila di kampus. Penelitian ini merupakan Penelitian Normatif. Pengembangan dan pendidikan Pancasila perlu dilakukan oleh perguruan tinggi dalam rangka melestarikan nilai-nilai Pancasila dan menanamkan nilai moral positif, yang terkandung di dalamnya pada generasi muda khususnya mahasiswa keberadaan mahasiswa yang mempunyai penting dan vital. Selain itu karena Pancasila sebagai dasar negara dan kepribadian bangsa Indonesia. Pancasila sebagai pandangan hidup bangsa harus dari dini dikenalkan dan diajarkan kepada masayarakat Indonesia termasuk di Perguruan Tinggi. Sebagai pembentuk intelektual yang bermoral ketuhanan dan kemanusian. Pancasila merupakan kepribadian bangsa, harus menjadi kepribadian para generasi muda khususnya para mahasiswa yang menjadi generasi pendidikan. Melalui pendidikan Pancasila, mahasiswa akan menjadi manusia terlebih dahulu, sebelum memasuki Ipteks yang dipelajarinya. Menjadi warga negara Indonesia yang unggul dalam penguasaan Ipteks, namun tidak kehilangan jati dirinya dan tidak tercabut dari akar budaya bangsanya dan keimanannya. Selain itu dapat membentuk pribadi yang baik dalam bermasyarakat dan dapat menanamkan norma-norma yang baik agar dapat menjadi warga negara yang baik bagi diri sendiri, orang lain dan bangsa ini dalam berkehidupan sehari-hari. Dalam mengamalkan nilai-nilai Pancasila dalam mahasiswa kita dapat melakukannya dalam beberapa jalur, yaitu jalur pendidikan dan jalur organisasi serta pengamalan secara objektif dan subjektif. Bila nilai-nilai Pancasila tertanam dengan baik di setiap individu mahasiswa, maka akan tercipta mahasiswa Pancasila yang mengerti norma-norma. Pengamalan Pancasila dalam kehidupan di kampus sangatlah amat penting demi memajukan Perguruan Tinggi agar kampus dapat menghasilkan lulusan mahasisiwa Pancasila yang dapat membangun bangsa Indonesia.
\end{abstract}

Kata Kunci: Mahasiswa, Pancasila, Pendidikan. 
Di dalam Undang-Undang Nomor 2 Tahun 1989 tentang sistem Pendidikan Nasional dan juga termuat dalam SK Dirjen Dikti No 38/DIKTI/Kep/ 2002, dijelaskan bahwa tujuan Pendidikan Pancasila mengarahkan perhatian pada moral yang diharapkan terwujud dalam kehidupan yaitu perilaku yang mencerminkan iman dan taqwa terhadap Tuhan Yang Maha Esa yang terdiri atas berbagai golongan agama dan budaya. Tujuan pendidikan diartikan sebagai seperangkat tindakan intelektual penuh tanggung jawab pada kompetensi mahasiswa pada bidang profesi masing-masing. Kompetensi pendidikan Pancasila adalah seperangkat tindakan intelektual yang berlandaskan nilai-nilai Pancasila.

Hakikatnya kewarganegaraan itu merupakan hasil dari sintesis antara civic education, democracy education, serta citizenship yang berlandaskan pada filsafat Pancasila serta mengandung identitas nasonal Indonesia serta materi muatan tentang bela negara. Dengan hakikat Pendidikan Kewarganegaraan Indonesia yang berbasis Pancasila tersebut, maka dapat dirumuskan bahwa Pendidikan Kewarganegaraan di Indonesia merupakan pendidikan kebangsaan dan kewarganegaraan yang berhadapan dengan keberadaan Negara Kesatuan Republik Indonesia, demokrasi, HAM, dan cita-cita untuk mewujudkan masyarakat madani Indonesia dengan menggunakan filsafat Pancasila sebagai pisau analisisnya (Kaelan dan Zubaidi, 2007, 1).

Mahasiswa adalah bibit unggul bangsa yang di mana pada masanya nanti bibit ini akan melahirkan pemimpin dunia. Karena itulah diperlukan pendidikan moral dan akademis yang akan menunjang sosok pribadi mahasiswa. Kepribadian mahasiswa akan tumbuh seiring dengan waktu dan mengalami proses pembenahan, pembekalan, penentuan, dan akhirnya pemutusan prinsip diri. Negara, masyarakat masa datang, diperlukan ilmu yang cukup untuk dapat mendukung kokohnya pendirian suatu Negara.
Dasarnya Mahasiswa dididik untuk menjadi generasi penerus bangsa yang memiliki pemikiran yang luas, realistis dan sistematis dalam menjalankan ketatanegaran. Generasi muda adalah generasi penerus perjuangan bangsa, oleh karena itu sangat perlu apabila dalam diri pribadi mereka ditanamkan nilai-nilai budaya bangsa yang telah diyakini kebenarannya, diterima, diikuti, dibela dan diperjuangkan selama ini. Nilai yang dimaksud adalah yang terkandung dalam sila-sila Pancasila, yang meliputi nilai Ketuhanan, kemanusiaan, persatuan, kerakyatan dan keadilan. Tanpa ada proses sosialisasi nilai-nilai Pancasila kepada generasi muda, maka nilai-nilai luhur Pancasila tidak akan dikenalnya, bahkan akan diabaikan. Bila hal ini dibiarkan, maka akibatnya dalam diri generasi muda terjadi kegelisahan, kegalauan dan kegoyahan karena tidak mantapnya kepribadian mereka. Hal yang demikian ini sangat membahayakan keberadaan bangsa Indonesia, karena tidak menutup kemungkinan akan terjadi konflik yang berkepanjangan yang akhirnya akan memecah persatuan dan kesatuan bangsa. Melalui pendidikan Pancasila diharapkan nilai-nilai luhur Pancasila tersebut dapat tersosialisasi bahkan terinternalisasi dalam diri pribadi generasi muda, khususnya mahasiswa, dan dalam diri mereka akan tumbuh sikap demokratis serta analitis kritis dalam menghadapi segala permasalahan kehidupan dan dalam mengaktualisasikan nilai-nilai Pancasila.

Mengingat Pancasila adalah dasar Negara, maka mengamalkan dan mengamankan Pancasila sebagai dasar negara mempunyai sifat imperatif/ memaksa artinya setiap warga negara Indonesia harus tunduk/taat kepadanya. Pengamalan Pancasila dalam hidup sehari-hari tidak disertai sanksisanksi hukum, tetapi mempunyai sifat mengikat artinya setiap manusia Indonesia terkait dalam cita-cita yang terkandung di dalamnya.

Berdasarkan hal di atas, elaborasi permasalahan di dalam analisis ini adalah tentang bagaimanakah makna atau eksistensi Pendidikan Pan- 
casila bagi mahasiswa, dan berkenaan dengan upaya atau cara pengamalan Pancasila di kampus.

\section{Pengertian Pancasila}

Pancasila adalah merupakan pedoman bagi semua warga bangsa Indonesia untuk berinteraksi dalam konteks kebersamaan untuk mengokohkan Negara Kesatuan Republik Indonesia. Oleh karena itu, Pendidikan Kewarganegaraan tidak dapat dilepaskan keterkaitannya dengan Pancasila. Pancasila menjadi roh bagi Pendidikan Kewarganegaraan (Wahidin, 2015, 6).

Pancasila sebagai filsafat bangsa Indonesia telah dipilih berdasarkan perenungan yang mendalam oleh the founding futhers bangsa Indonesia. Oleh sebab itu, keyakinan terhadap Pancasila sebagai falsafah bangsa merupakan akar kebenaran untuk memahami eksistensi bangsa Indonesia. Di mana pun berada, dalam arti kendatipun tidak dalam wilayah Indonesia, namun manakala dirinya adalah warga bangsa Indonesia maka Pancasila menjadi filsafat hidupnya.

Pengertian Pancasila sebagai dasar negara yang dimaksud sesuai dengan bunyi pembukaan pada Undang-Undang Dasar 1945 Alinea IV yang menyatakan kemudian dari pada itu untuk membentuk suatu pemerintahan negara Indonesia yang melindungi segenap bangsa Indonesia dan seluruh tumpah darah Indonesia dan untuk memajukan kesejahteraan umum, mencerdaskan kehidupan bangsa, dan ikut melaksanakan ketertiban dunia yang berdasarkan kemerdekaan, perdamaian abadi dan keadilan sosial. Maka disusunlah kemerdekaan kebangsaan Indonesia itu dalam suatu Undang-Undang dasar Negara Republik Indonesia yang membentuk dalam suatu susunan negara Indonesia yang berkedaulatan rekyat dengan berdasarkan kepada ketuhanan Yang Maha Esa, kemanusiaan yang adil dan beradab, persatuan Indonesia, dan kerakyatan yang dipimpin oleh hikmat kebijaksanaan dalam permusyawaratan perwakilan, serta dengan mewujudkan suatu keadilan sosial bagi seluruh rakyat Indonesia. Norma hukum pokok yang disebut pokok kaidah fundamental dari negara itu dalam hukum mempunyai hakikat dan juga kedudukan yang kuat, tetap, dan tidak berubah bagi negara yang terbentuk dengan perkataan lain. Dengan jalan hukum tidak bisa diubah-ubah. Fungsi dari Pancasila sebagai pokok kaidah yang fundamental. Hal yang paling penting sekali karena Undang-Undang Dasar harus berasal dan berada di bawah pokok kaidah negara yang fundamental itu.

Pancasila sebagai suatu sistem filsafat, memiliki dasar ontologis, dasar epistemologis dan dasar aksiologis tersendiri, yang membedakannya dengan sistem filsafat lain. Secara ontologis, kajian Pancasila sebagai filsafat dimaksudkan sebagai upaya untuk mengetahui hakekat dasar dari silasila Pancasila. Notonagoro menyatakan bahwa hakekat dasar ontologis Pancasila adalah manusia, sebab manusia merupakan subjek hukum pokok dari Pancasila (Notonegoro, 2004, 7). Dalam Pancasila terkadung nilai material, nilai vital, nilai kebenaran, nilai keindahan, nilai kebaikan maupun nilai kesucian. Jadi pada Pancasila terkandung nilainilai secara harmonis dan sistematis, yang dimulai dari sila Ketuhanan Yang Maha Esa sebagai "dasar" sampai dengan sila Keadilan Sosial bagi Seluruh Rakyat Indonesia sebagai tujuan (Darmodiharjo dan Sidarta, 1995, 211).

\section{Tujuan Pendidikan Kewarganegaraan}

Adanya pendidikan kewarganegaraan bagi bangsa Indonesia akan senantiasa diupayakan untuk membentuk manusia Indonesia seutuhnya, sebagaimana yang diamanatkan Pembukaan Undang-Undang Dasar 1945, yakni sebagai manusia Indonesia yang religius, berkemanusiaan dan berkeadaban, yang memiliki nasionalisme, yang cerdas, yang berkerakyatan dan yang adil terhadap lingkungan sosialnya (Erwin, 2013, 6). 
Tujuan diadakannya Pendidikan Kewarganegaraan untuk tataran mahasiswa jika berdasarkan Keputusan Direktorat Jenderal Pendidikan Tinggi No. 43/DIKTI/Kep/2006, tujuan diadakannya Pendidikan Kewarganegaraan telah dirumuskan dalam visi dan misi sebagai berikut: Visi Pendidikan Kewarganegaraan di perguruan tinggi adalah merupakan sumber nilai dan pedoman dalam pengembangan dan penyelenggaraan program studi, guna menghantarkan mahasiswa memantapkan kepribadianya sebagai manusia seutuhnya.

Hal di atas berdasarkan pada suatu realitas yang dihadapi, bahwa manusia adalah sebagai generasi bangsa yang harus memiliki visi intelektual, religius berkeadaban, berkemanusiaan, dan cinta tanah air dan bangsanya. Misi Pendidikan Kewarganegaraan di perguruan tinggi adalah untuk membantu mahasiswa memantapkan kepribadiannya, agar secara konsisten mampu mewujudkan nilai-nilai dasar Pancasila, rasa kebangsaan dan cinta tanah air dalam menguasai, menerapkan dan mengembangkan ilmu pengetahuan, teknologi, dan seni dengan rasa tanggung jawab dan bermoral (Erwin, 2013, 7).

\section{Kedudukan dan Fungsi Pancasila}

Kedudukan dan fungsi Pancasila dalam negara dan bangsa Indonesia menurut Munir dkk (2016, 18) adalah sebagai berikut:

1. Pancasila sebagai Jiwa Bangsa Indonesia Pancasila sebagai bangsa adanya/lahirnya bersamaan dengan adanya Bangsa Indonesia. Jiwa bangsa Indonesia mempunyai arti statis (tetap/ tidak berubah) dan mempunyai arti dinamis (bergerak). Jiwa ini diwujudkan dalam sikap mental dan tingkah laku serta amal/perbuatan. Pancasila melekat erat pada kehidupan bangsa Indonesia dan menentukan eksistensi bangsa Indonesia. Segala aktivitas bangsa Indonesia disemangati oleh Pancasila.
2. Pancasila sebagai kepribadian bangsa Indonesia Sikap mental, tingkah laku dan amal perbuatan bangsa Indonesia mempunyai ciri-ciri khas yang dapat membedakan dengan bangsa lain. Pancasila merupakan pilihan unik yang paling tepat bagi bangsa Indonesia, karena merupakan cerminan sosio-budaya bangsa Indonesia sendiri sejak adanya di bumi Nusantara. Secara integral, Pancasila adalah "materai" yang khas Indonesia.

3. Pancasila sebagai Pandangan Hidup Bangsa Indonesia

Nilai-nilai yang tekandung dalam Pancasila dipergunakan sebagai petunjuk, penuntun, dan pegagangan dalam mengtur sikap dan tingkah laku manusia Indonesia dalam kehidupan bermasyarakat, berbangsa dan bernegara.

4. Pancasila sebagai Falsafah Hidup Bangsa Indonesia

Pancasila oleh bangsa Indonesia diyakini benar-benar memiliki kebenaran. Falsafah berarti pula pandangan hidup, sikap hidup, pegangan hidup, atau tuntunan hidup. Pancasila juga merupakan hasil proses berpikir yang menyeluruh dan mendalam dalam mengenal hakikat diri bangsa Indonesia, sehingga merupakan pilihan yang tepat dan satu-satunya untuk bertingkah laku sebagai manusia Indonesia dalam kehidupan bermasyarakat, berbangsa dan bernegara.

5. Pancasila sebagai Ideologi Negara Republik Indonesia

Pancasila sebagai ideologi bangsa dan negara Indonesia berakar pada pandangan hidup dan budaya bangsa, dan bukannya mengangkat atau mengambil ideologi dari bangsa lain. Pancasila sebagai ideologi negara merupakan tujuan bersama Bangsa Indonesia yang diimplementasikan dalam Pembangunan Nasional yaitu mewujudkan masyarakat adil dan makmur yang merata baik material dan spiritual 
berdasarkan Pancasila dalam wadah Negara Kesatuan RI yang merdeka, berdaulat, bersatu dan berkedaulatan rakyat dalam suasana perikehidupan bangsa yang aman, tentram, tertib dan dinamis serta dalam lingkungan pergaulan dunia yang merdeka, bersahabat, tertib dan damai.

6. Pancasila sebagai Perjanjian Luhur Bangsa Indonesia

Pancasila telah disepakati dan disetujui oleh rakyat Indonesia melalui perdebatan dan tukar pikiran baik dalam sidang BPUPKI maupun PPKI oleh para pendiri Negara. Perjanjian luhur tersebut dipertahankan terus oleh negara dan bangsa Indonesia. Kita semua mempunyai janji untuk melaksanakan, mempertahankan serta tunduk pada asas Pancasila.

7. Pancasila sebagai Dasar Negara Republik Indonesia

Sebagai dasar Negara, Pancasila merupakan suatu asas kerohanian yang meliputi suasana kebatinan atau cita-cita hukum, sehingga merupakan suatu sumber nilai, norma serta kaidah, baik moral maupun hukum negara dan menguasai hukum dasar baik yang tertulis dalam Undang-Undang Dasar maupun yang tidak tertulis atau konvensi. Dalam kedudukannya sebagai dasar Negara, Pancasila mempunyai kekuatan mengikat secara hukum.

8. Pancasila sebagai Sumber Hukum Nasional Pancasila merupakan sumber dari segala sumber hukum. Pancasila merupakan sumber kaidah hukum negara yang secara konstitusional mengatur negara Republik Indonesia beserta seluruh unsur-unsurnya yaitu rakyat, wilayah, serta pemerintahan negara. Sebagai sumber dari segala sumber hukum atau sebagai sumber tertib hukum Indonesia maka Pancasila tercantum dalam ketentuan tertinggi yaitu Pembukaan Undang-Undang Negara Kesatuan RI tahun 1945, kemudian dijelmakan atau dijabarkan lebih lanjut dalam pokok-pokok pikiran, yang meliputi suasana kebatinan dari Undang-Undang Negara Kesatuan RI tahun 1945. Pada akhirnya dijabarkan dalam pasalpasal Undang-Undang Negara Kesatuan RI tahun 1945, serta hukum positif lainnya.

\section{Metode Penelitian}

Berdasarkan bidang kajiannya, penelitian hukum ini merupakan Penelitian Normatif, yaitu penelitian yang dilakukan dengan cara mengkaji aturan-aturan hukum dan bahan-bahan hukum pendukung lainnya yang terkait makna Pancasila bagi mahasiswa dan pengalaman Pancasila di kampus. Penelitian Normatif juga sering disebut sebagai penelitian Doctrinal, yaitu penelitian dengan obyek kajiannya adalah dokumen-dokumen atau bahan-bahan pustaka.

Suatu penelitian hukum normatif dapat dibatasi pada penggunaan studi dokumen atau bahan pustaka saja (yaitu pada data sekunder). Data sekunder diperoleh dengan mengkaji dan menganalisa kepustakaan atau dokumen. Data sekunder yaitu data yang berdasarkan teknik penelusuran bahan dan dokumen hukum, terbagi atas:

1. Bahan hukum primer, yaitu bahan yang isinya mengikat karena dikeluarkan oleh pemerintah atau bahan hukum primer adalah bahan yang harus ada dalam penelitian yang mempunyai kekuatan mengikat dan dalam keadaan siap terbukti, seperti Undang-Undang Dasar 1945.

2. Bahan hukum sekunder, yaitu bahan yang memberikan penjelasan atau bersifat menunjang terhadap bahan hukum primer atau dengan kata lain bahan hukum hukum sekunder dapat berupa bahan-bahan yang erat hubungannya dengan bahan hukum primer. Bahan hukum sekunder dalam penelitian ini terdiri dari:

a. Buku-buku atau literatur-literatur yang berhubungan Pancasila;

b. Makalah-makalah, artikel-artikel dan karya tulis. 
Untuk menganalisa bahan hukum atau menarik kesimpulan dari hasil penelitian maka terhadap bahan hukum yang diperoleh dari penelusuran bahan hukum primer dan sekunder, penulis menggunakan metode analisa isi atau content analysis. Analisa isi (content analysis) adalah teknik penelitian untuk membuat inferensi-inferensi yang dapat ditiru (replicable), dan sahih bahan hukum dengan memperhatikan konteksnya. Artinya untuk memperoleh kesimpulan atas rumusan permasalahan, dilakukan analisa terhadap data-data bahan hukum baik bahan hukum primer dan sekunder.

\section{Makna Pancasila Bagi Mahasiswa}

Pancasila merupakan ajaran, gagasan dan keyakinan sebagai acuhan tingkah laku masyarakat Indonesia dalam berbagai bidang kehidupan, baik di bidang politik, ekonomi, hukum, pertahanan keamanan (Hankam), Sosial, Kebudayaan, keagamaan, maupun Pendidikan, sehingga dalam setiap tindakannya, selalu mengacu kepada Pancasila sebagai dasarnya. Tapi tidak bisa kita pungkiri, bahwa pemuda sebagai generasi penerus bangsa sekarang kurang begitu memahami akan makna serta meresapi nilai-nilai yang terkandung dalam ideologi kita.

Generasi muda adalah generasi penerus perjuangan bangsa, oleh karena itu sangat perlu apabila dalam diri pribadi mereka ditanamkan nilainilai budaya bangsa yang telah diyakini kebenarannya, diterima, diikuti, dibela dan diperjuangkan selama ini. Nilai yang dimaksud adalah yang terkandung dalam sila-sila Pancasila, yang meliputi nilai Ketuhanan, kemanusiaan, persatuan, kerakyatan dan keadilan. Tanpa ada proses sosialisasi nilai-nilai Pancasila kepada generasi muda, maka nilai-nilai luhur Pancasila tidak akan dikenalnya, bahkan akan diabaikannya. Bila hal ini dibiarkan, maka akibatnya dalam diri generasi muda terjadi kegelisahan, kegalauan dan kegoyahan karena tidak mantapnya kepribadian mereka.
Hal yang demikian ini sangat membahayakan keberadaan bangsa Indonesia, karena tidak menutup kemungkinan akan terjadi konflik yang berkepanjangan yang akhirnya akan memecah persatuan dan kesatuan bangsa. Melalui pendidikan Pancasila diharapkan nilai-nilai luhur Pancasila tersebut dapat tersosialisasi bahkan terinternalisasi dalam diri pribadi generasi muda, khususnya mahasiswa, dan dalam diri mereka akan tumbuh sikap demokratis serta analitis kritis dalam menghadapi segala permasalahan kehidupan dan dalam mengaktualisasikan nilai-nilai Pancasila.

Undang-Undang Nomor 2 Tahun 1989 tentang sistem Pendidikan Nasional dan juga termuat dalam SK Dirjen Dikti. No.38/DIKTI/Kep/2003, dijelaskan bahwa tujuan Pendidikan Pancasila mengarahkan perhatian pada moral yang diharapkan terwujud dalam kehidupan sehari-hari, yaitu perilaku yang memancarkan iman dan taqwa terhadap Tuhan Yang Maha Esa dalam masyarakat yang terdiri atas berbagai golongan agama, kebudayaan, dan beraneka ragam kepentingan, perilaku yang mendukung kerakyatan yang mengutamakan kepentingan bersama di atas kepentingan perorangan dan golongan sehingga perbedaan pemikiran diarahkan pada perilaku yang mendukung upaya terwujudnya keadilan sosial bagi seluruh rakyat Indonesia.

Pendidikan Pancasila bertujuan untuk menghasilkan mahasiswa yang beriman dan bertaqwa terhadap Tuhan Yang Maha Esa, seperti sikapsikap di bawah ini, sehingga dapat diamalkan dikemudian hari:

1. Memiliki kemampuan untuk mengambil sikap yang bertanggungjawab sesuai dengan hati nuraninya.

2. Memiliki kemampuan untuk mengenali masalah hidup dan kesejahteraan serta cara-cara pemecahannya.

3. Mengenali perubahan-perubahan dan perkembangan ilmu pengetahuan, teknologi dan seni. 
4. Memiliki kemampuan untuk memaknai peristiwa sejarah dan nilai-nilai budaya bangsa untuk menggalang persatuan Indonesia.

Persatuan Indonesia sangat diharapkan oleh seluruh masyarakat Indonesia. Dengan memaknai setiap peristiwa sejarah dan nilai-nilai budaya Indonesia diharapkan dapat membuat Indonesia bersatu. Melalui Pendidikan Pancasila, warga negara Republik Indonesia diharapkan mampu memahami, menganilisis dan menjawab masalahmasalah yang dihadapi oleh masyarakat bangsanya secara berkesinambungan dan konsisten berdasarkan cita-cita dan tujuan bangsa Indonesia.

Berkaitan dengan pentingnya pendidikan Pancasila di perguruan tinggi, yaitu seberapa jauh pentingnya pendidikan Pancasila bagi mahasiswa dilaksanakan di perguruan tinggi. Memahami hakekat Pancasila berarti memahami makna Pancasila. Artinya dalam kehidupan berbangsa dan bernegara bahwa Pancasila mempunyai fungsi dan peran tersendiri. Sudah jelas Pancasila dasar negara, namun di samping itu Pancasila mempunyai fungsi sebagai pandangan hidup bangsa. Artinya bahwa pandangan hidup sebuah bangsa lahir dari nilai-nilai yang dimiliki bangsa itu sendiri, yang diyakini kebenarannya dan menimbulkan tekad untuk mewujudkan.

Melihat betapa pentingnya fungsi Pancasila dalam kehidupan bangsa Indonesia maka sudah seharusnya Pancasila dipahami secara menyeluruh dan mendalam oleh orangnya sendiri. Salah satu sarana dalam proses memahami Pancasila adalah melalui pendidikan formal mulai dari tingkat dasar sampai tingkat perguruan tinggi. Pendidikan Pancasila sudah diatur sedemikian rupa dalam sebuah peraturan. Dasar hukum pelaksanaan pendidikan Pancasila di lembaga pendidikan formal bersumber pada TAP MPR no II/MPR/1998 tentang GBHN yang menetapkan antara lain: pendidikan Pancasila termasuk pendidikan pedoman penghayatan dan pengamalan Pancasila, pendidik- an moral Pancasila, pendidikan sejarah perjuangan bangsa serta unsur-unsur yang dapat meneruskan dan mengembangkan jiwa, semangat dan nilai-nilai perjuangan khususnya nilai-nilai 45 pada generasi muda, dilanjutkan dan makin ditingkatkan disemua jenis jenjang pendidikan mulai dari TK sampai perguruan tinggi negeri maupun swasta.

Perguruan tinggi yang berperan dalam mengembangkan dan memperdalam pengetahuan dan mengajarkannya dan memperoleh pengetahuan. Bahkan berbagai masalah yang sedang terjadi di negara ini bisa dilestarikan dari memperdalam dan menemukan sebuah solusi melalui pemahaman yang mendalam tentang Pancasila. Melalui pendidikan Pancasila, diharapkan juga para mahasiswa memahami, menganalisis dan menjawab masalahmasalah yang dihadapi masyarakat, bangsa secara berkesinambungan dan konsisten, dengan cita-cita tujuan nasional. Di samping itu mahasiswa memiliki kemampuan untuk mengambil sikap bertanggung jawab sesuai dengan hati nurani serta memaknai perestiwa sejarah dan nilai-nilai budaya bangsa untuk menggalang persatuan Indonesia. Selain itu dengan pengajaran ditingkat perguruan tinggi memungkinkan mahasiswa menerapkan sehingga nilai-nilai moral Pancasila terkandung dalam sila-sila Pancasila masuk dalam kepribadian mahasiswa.

Adapun tujuan pendidikan Pancasila di Perguruan Tinggi adalah agar mahasiswa:

1. Dapat memahami dan mampu melaksanakan jika Pancasila dan Undang-Undang Dasar 1945 dalam kehidupan sebagai warga negara Indonesia.

2. Menguasai pengetahuan tentang beragam masalah dasar berkehidupan bermasyarakat, berbangsa dan bernegara yang hendak diatasi dengan penerapan pemikiran yang berlandasan Pancasila dan Undang-Undang Dasar 1945.

3. Memupuk sikap dan perilaku yang sesuai dengan nilai-nilai dan norma Pancasila, se- 
hingga mampu menanggapi perubahan yang terjadi dalam rangka keterpaduan Iptek dan pembangunan.

4. Membantu mahasiswa dalam proses belajar, proses berpikir, memecahkan masalah dan mengambil keputusan dengan menerapkan strategi heuristik terhadap nilai-nilai Pancasila.

Tujuan mempelajari Pancasila adalah mengetahui Pancasila yang benar, yakni yang dapat dipertangung jawabkan baik secara yuridis. Secara yuridis-konstitusional karena Pancasila adalah dasar negara yang dipergunakan sebagai dasar pengatur/menyelenggarakan pemerintahan negara. Secara objektif ilmiah karena Pancasila adalah suatu paham filsafat, yang uraiannya harus logis dan dapat diterima oleh akal sehat.

Selanjutnya Pancasila yang benar itu diamalkan sesuai dengan fungsinya dan kemudian Pancasila yang benar kita amalkan agar jiwa dan semangat, perumusan, sistematiknya sudah tepat dan benar. Tujuan itu sebenarnya bertitik tolak pada salah satu manusia yaitu sifat atau hasrat "ingin tahu".

Mengingat Pancasila adalah dasar negara maka mengamalkan dan mengamankan Pancasila sebagai dasar negara mempunyai sipat imperatif/ memaksa artinya setiap warga negara Indonesia harus tunduk/taat kepadanya. Pengamalan Pancasila dalam hidup sehari-hari tidak disertai sanksisanksi hukum, tetapi mempunyai sifat mengikat artinya setiap manusia Indonesia terkait dalam cita-cita yang terkandung di dalamnya.

Pendidikan Pancasila bertujuan untuk menghasilkan peserta didik yang beriman dan bertakwa kepada Tuhan Yang Maha Esa, berperikemanusiaan yang adil dan beradab, mendukung kerakyatan yang mengutamakan upaya mewujudkan suatu keadlan sosial dalam masyarakat.

Pendidikan Pancasila adalah suatu usaha sadar, yang terencana dan terarah, melalui pendi- dikan formal, untuk mentransformasikan nilai-nilai yang terkandung dalam Pancasila pada mahasiswa. Mahasiswa diharapkan dapat mencerna nilai-nilai Pancasila melalui akalnya, dan menumbuhkan rasionalitas sesuai dengan kemampuan, sehingga anak mencapai perkembangan penalaran moral seoptimal mungkin yang dijiwai Pancasila.

Pendidikan Pancasila mempunyai kedudukan yang sangat penting, khususnya dalam pembentukan kepribadian manusia Indonesia, yaitu kepribadian yang dijiwai oleh nilai-nilai Pancasila. Sasaran terakhir dari Pedidikan Pancasila adalah dipahami, dihayati dan diamalkan Pancasila oleh setiap mahasiswa di dalam kehidupan bermasyarakat dan bernegara. Karena Pendidikan Pancasila ternyata diberikan pada setiap tingkat dan jenjang pendidikan formal, diharapkan nilai-nilai Pancasila dapat dicerna dan diterima mahasiswa menurut tingkat pengalaman dan perkembangan penalarannya. Dalam setiap jenjang perkembangannya, diharap mahasiswa mampu menemukan relevansi nilai-nilai Pancasila bagi kehidupannya, sehingga mampu mentransformasikan nilai-nilai tersebut dalam kehidupan nyata sehari-hari.

Tingkat perguruan tinggi, mahasiswa perlu dituntut untuk dapat bertindak secara bertanggung jawab. Mereka tidak hanya bertindak atas dasar peraturan perundangan yang ada, melainkan menyadari bahwa tindakan yang dipilihnya memang merupakan tindakan yang bernilai. Berkaitan dengan pengamalan Pancasila, mereka bertindak sesuai dengan Pancasila bukan hanya karena ditunjukkan bahwa Pancasila itu baik, melainkan mereka diharap telah mencerna dengan akalnya serta berkeyakinan bahwa Pancasila sungguh bernilai bagi dirinya serta seharusnya layak diamalkan. Mereka diharap dapat memahami dan menghayati bahwa Pancasila sungguh-sungguh bernilai, dan akhirnya mendorong dirinya untuk mewujudkan nilai-nilai Pancasila dalam kehidupan seharihari. 


\section{Makna Sila-Sila Pancasila}

a. Arti dan Makna Sila Ketuhanan Yang Maha Esa Manusia sebagai makhluk yang ada di dunia ini seperti halnya makhluk lain diciptakan oleh penciptanya. Pencipta itu adalah kuasa prima yang mempunyai hubungan dengan yang diciptakannya. Manusia sebagai makhluk yang diciptakan wajib melaksanakan perintah Tuhan dan menjauhi larangan-Nya. Arti dan Makna Sila Ketuhanan Yang Maha Esa

1) Percaya dan taqwa kepada Tuhan Yang Maha Esa sesuai dengan agama dan kepercayaannya masing-masing menurut dasar kemanusiaan yang adil dan beradab.

2) Hormat dan menghormati serta bekerjasama antara pemeluk agama dan penganut-penganut kepercayaan yang berbeda-beda sehingga terbina kerukunan hidup.

3) Saling menghormati kebebasan menjalankan ibadah sesuai dengan agama dan kepercayaan masing-masing.

4) Tidak memaksakan suatu agama atau kepercayaannya kepada orang lain.

b. Arti dan Makna Sila Kemanusiaan yang Adil dan Beradab

1) Menempatkan manusia sesuai dengan hakikatnya sebagai makhluk Tuhan.

2) Menjunjung tinggi kemerdekaan sebagai hak segala bangsa.

3) Mewujudkan keadilan dan peradaban yang tidak lemah.

4) Manusia ditempatkan sesuai dengan harkatnya. Hal ini berarti bahwa manusia mempunyai derajat yang sama di hadapan hukum. Sejalan dengan sifat universal bahwa kemanusiaan itu dimiliki oleh semua bangsa, maka hal itupun juga kita terapkan dalam kehidupan bangsa Indonesia. Sesuai dengan hal itu, hak kebebasan dan kemerdekaan dijunjung tinggi.
5) Mengakui persamaan derajat, persamaan hak dan persamaan kewajiban antara sesama manusia.

6) Saling mencintai sesama manusia.

7) Mengembangkan sikap tenggang rasa.

8) Tidak semena-mena terhadap orang lain.

9) Menjunjung tinggi nilai kemanusiaan.

10) Gemar melakukan kegiatan kemanusiaan.

11) Berani membela kebenaran dan keadilan.

12) Bangsa Indonesia merasa dirinya sebagai bagian dari masyarakat Dunia Internasional dan dengan itu harus mengembangkan sikap saling hormat-menghormati dan bekerjasama dengan bangsa lain.

c. Arti dan Makna Sila Persatuan Indonesia Pokok-pokok pikiran yang perlu dipahami antara lain: Nasionalisme, cinta bangsa dan tanah air, menggalang persatuan dan kesatuan bangsa, menghilangkan penonjolan kekuatan atau kekuasaan maupun warna kulit dan keturunan, menumbuhkan rasa senasib sepenanggungan. Makna persatuan hakekatnya adalah satu, yang artinya bulat, tidak terpecah. Jika persatuan Indonesia dikaitkan dengan pengertian modern sekarang ini, maka disebut nasionalisme. Oleh karena rasa satu yang sedemikian kuatnya, maka timbulah rasa cinta bangsa dan tanah air.

1) Menjaga Persatuan dan Kesatuan Negara Kesatuan Republik Indonesia.

2) Rela berkorban demi bangsa dan negara.

3) Cinta akan Tanah Air.

4) Berbangga sebagai bagian dari Indonesia.

5) Memajukan pergaulan demi persatuan dan kesatuan bangsa yang ber-Bhinneka Tunggal Ika.

d. Arti dan Makna Sila Kerakyatan yang Dipimpin oleh Hikmat Kebijaksanaan dalam Permusyawaratan/Perwakilan.

Pada hakikatnya sila ini adalah demokrasi. Perbedaan secara umum demokrasi di barat dan di Indonesia yaitu terletak pada permusya- 
waratan. Permusyawaratan artinya mengusahakan putusan bersama secara bulat, baru sesudah itu diadakan tindakan bersama. Kebijaksaan ini merupakan suatu prinsip bahwa yang diputuskan itu memang bermanfaat bagi kepentingan rakyat banyak. Dalam melaksanakan keputusan dibutuhkan kejujuran bersama.

1) Mengutamakan kepentingan negara dan masyarakat.

2) Tidak memaksakan kehendak kepada orang lain.

3) Mengutamakan budaya rembug atau musyawarah dalam mengambil keputusan bersama.

4) Berembug atau bermusyawarah sampai mencapai konsensus atau kata mufakat diliputi dengan semangat kekeluargaan.

e. Arti dan Makna Sila Keadila Sosial Bagi Seluruh Rakyat Indonesia

1) Bersikap adil terhadap sesama.

2) Menghormati hak-hak orang lain.

3) Menolong sesama.

4) Menghargai orang lain.

5) Melakukan pekerjaan yang berguna bagi kepentingan umum dan bersama.

Keadilan berarti adanya persamaan dan saling menghargai karya orang lain. Jadi seseorang bertindak adil apabila dia memberikan sesuatu kepada orang lain sesuai dengan haknya.

Ada 3 macam keadilan

1) Keadilan legalis, yaitu keadilan yang arahnya dari pribadi ke seluruh masyarakat.

2) Keadilan distributif, yaitu keseluruhan masyarakat wajib memperlakukan manusia pribadi sebagai manusia yang sama martabatnya.

3) Kedilan komutatif, yaitu memperlakukan warga lain sebagi pribadi yang sama martabatnya.

Kemakmuran yang merata bagi seluruh rakyat dalam arti dinamis dan meningkat. Seluruh kekayaan alam dan sebagainya dipergunakan bagi kebahagian bersama menurut potensi masing-masing. Melindungi yang lemah agar kelompok warga masyarakat dapat bekerja sesuai dengan bidangnya.

Pancasila adalah dasar falsafah negara Indonesia sebagaimana tercantum dalam pembukaan Undang-Undang Dasar 1945. Setiap warga negara wajib mempelajari, mendalami, menghayati, dan mengamalkannya dalam segala bidang kehidupan. Seperti kita ketahui bersama, bahwa saat ini Indonesia berada dalam era globalisasi. Maka agar tidak terombang ambing di tengah masyarakat internasional, bangsa Indonesia harus memiliki visi dan ideologi yang kuat (nasionalisme). Terutama kita sebagai mahasiswa harus memiliki ideologi yang berdasarkan atas Pancasila. Sebab mahasiswa memiliki peran yang penting dalam masyarakat contohnya, sebagai kontrol sosial dan calon pemimpin bangsa. Dengan begitu setiap mahasiswa dan rakyat Indonesia pada umumnya harus mampu mengimplementasikan nilai-nilai Pancasila dalam kehidupan sehari-hari. Selain itu setiap warga Indonesia wajib menghayati nilai yang terkandung dalam sila-sila Pancasila secara utuh dan menyeluruh.

Agar terbentuk masyarakat yang berjiwa Pancasilaisme harus ada pendidikan Pancasila dalam setiap tingkat pendidikan formal, terutama untuk tingkat pendidikan tinggi. Karena di tingkat ini adalah fase paling rawan, artinya di tingkat ini banyak mahasiswa yang mencari pandangan hidup (ideologi) yang sesuai dengan dirinya. Disinilah peran Pancasila sebagai ideologi diperlukan sebagai penanaman karakter bagi mahasiswa. Karena hanya Pancasila yang sesuai dengan kepribadian bangsa Indonesia.

Pancasila sebagai dasar filsafat negara merupakan sumber bagi segala tindakan para penyelenggara negara, menjadi jiwa dari PerundangUndangan yang berlaku dalam kehidupan bernegara. Secara filosofis dan obyektif, nilai-nilai yang tertuang dalam sila-sila Pancasila merupakan filo- 
sofi bangsa Indonesia sebelum mendirikan negara Republik Indonesia. Maka dari itu, dalam menghadapi tantangan kehidupan bangsa dalam maraknya globalisasi, Bangsa Indonesia harus tetap memiliki nilai-nilai, yaitu Pancasila sebagai sumber nilai dalam pelaksanaan kenegaraan yang menjiwai pembangunan nasional di berbagai bidang.

Pancasila sebagai dasar falsafah bangsa merupakan satu kesatuan nilai yang tidak dapat dipisah-pisahkan dengan masing-masing silasilanya, karena apabila dilihat satu persatu dari masing-masing sila itu dapat saja ditemukan dalam kehidupan bangsa lain. Namun makna Pancasila terletak pada nilai-nilai dari masing-masin sila sebagai satu kesatuan yang tidak dapat ditukarbalikkan letak dan susunanya.

Merupakan kewajiban moral untuk merealisasikan nilai-nilai tersebut di atas dalam bidang kehidupan berbangsa dan bernegara. Adapun wujud realisasinya adalah melalui pendidikan Pancasila yang juga merupakan suatu media pendidikan berkarakter bagi setiap warga negara. Pancasila mencakup karakter nasional dan global, yakni etos kerja yang tinggi, bekerja keras, cinta tanah air, nasionalis, cerdas, kreatif, kritis, inovatif, bertanggung jawab, adil, bijaksana. Selain itu, karakter lainnya ialah bermental pemberani (patriotik), tekun, berwawasan kebangsaan dan global. Karakter berikutnya adalah visioner, mampu membuat pilihan dalam hidup, rukun, ramah, saling menghargai, jujur, sportif, dan tangguh.

Pendidikan Pancasila sebagai pendidikan berkarakter bagi setiap warga negara Indonesia memiliki peranan penting dalam upaya mewujudkan Indonesia yang maju dan bermartabat. Pendidikan Pancasila ini sangtalah penting diberikan khususnya bagi para mahasiswa. Di Perguruan Tinggi, Pendidikan karakter terintegrasi dalam Pendidikan Pancasila sebagai mata kuliah dasar umum yang wajib diikuti oleh seluruh mahasiswa. Pemberian mata kuliah Pendidikan Pancasila kepada setiap mahasiswa itu sebagai wujud pengem- bangan karakter, watak dan akhlak yang sesuai dengan nilai-nilai Pancasila dimaksudkan untuk mencegah timbulnya radikalisme yang membahayakan negara, dan juga agar setiap mahsiswa dapat memahami dan mengemalkan nilai-nilai Pancasila.

Perlu diketahui bahwasanya dalam sektor modern Perguruan Tinggi (Universitas) dianggap sebagai lembaga paling modern dan pembaruan. Perguruan tinggi ialah sebuah pusat dengan peranannya menghasilkan pemimpin yang cocok di masa kini dan mempelopori modernisasi. Eksistensi mahasiswa sebagai generasi muda merupakan ujung tombak harapan bangsa, ia adalah aset berharga untuk masa depan Indonesia. Maka dari itu, untuk menjadi bangsa yang berdaulat, berdikari, dan unggul, setiap generasi muda harus memiliki karakter Pancasila sebagaimana yang telah dipaparkan sebelumnya. Dengan pendidikan Pancasila, mahasiswa didambakan menjadi warganegara Indonesia yang unggul dalam penguasaan Iptek dan seni, namun tidak kehilangan jati dirinya, apalagi tercabut dari karya budaya bangsa dan keimanannya. Adapun tujuan pendidikan Pancasila sebagai pendidkan berkarakter adalah sebagai berikut; Pendidikan Pancasila mengarahkan perhatian pada moral yang diharapkan diwujudkan dalam kehidupan sehari-hari, yaitu perilaku yang memancarkan iman dan takwa terhadap Tuhan Yang Maha Esa dalam masyarakat yang terdiri atas berbagai golongan agama, perilaku yang bersifat kemanusiaan yang adil dan beradab, perilaku kebudayaan, dan beraneka ragam kepentingan perilaku yang mendukung kerakyatan yang mengutamakan kepentingan bersama di atas kepentingan perorangan dan golongan. Dengan demikian perbedaan pemikiran, pendapat atau kepentingan diatasi melalui keadilan sosial bagi seluruh rakyat Indonesia.

Pendidikan Pancasila sebagai salah satu dari mata kuliah memiliki misi dan visi; Misi Pendidikan Pancasila: Misi pendidikan Pancasila di perguruan tinggi menjadi sumber nilai dan pedoman bagi 
penyelenggaraan program studi dalam mengantarkan mahasisiwa mengembangkan kepribadiaannya.

Visi Pendidikan Pancasila: Bertujuan membantu mahasiswa agar mampu mewujudkan nilai dasar agama dan kebudayaan serta kesadaran berbangsa dan bernegara dalam menerapkan ilmu pengetahuan, teknologi, dan seni yang dikuasainya dengan rasa tanggung jawab kemanusiaan.

Pendidikan Pancasila yang berhasil akan membuahkan sikap mental bersifat cerdas penuh tanggung jawab dari peserta didik dengan perilaku yang, Beriman dan bertakwa terhadap TuhanYang Maha Esa, Berperikemanusiaan yang adil dan beradab, mendukung persatuan bangsa, mendukung kerakyatan yang mengutamakan kepentingan bersama di atas kepentingan perorangan dan mendukung upaya untuk mewujudkan keadilan sosial.

Perlu diingat bersama bahwasannya pentingnya pendidikan karakter Pancasila tidak sebatas untuk menanggapi isu-isu aktual dan dijadikan sebagai komoditas iklan pendidikan, tetapi ada capaian-capaian masa depan yang harus diraih, yakni membangun bangsa yang berdaulat, mandiri, dan unggul.

\section{Implementasi Pancasila dalam Kehidupan Kampus}

Kampus juga harus memerlukan tatanan pembangunan seperti tatanan Negara yaitu politik, ekonomi, budaya, hukum dan antar umat beragama. Sebagai mahasiswa yang mempunyai rasa intelektual yang besar kita dapat memanfaatkan fasilitas kampus untuk mencapai tujuan bersama.

a. Implementasi Sila I: Ketuhanan yang Maha Esa

1) Jadwal kuliah sudah diatur sedemikian rupa sehingga tidak mengganggu jadwal untuk beribadah.

2) Mahasiswa baru diwajibkan untuk mengikuti ospek/pengenalan kampus.
3) UKM (Unit Kegiatan Mahasiswa) kerohanian, misalnya UKM mahasiswa Budha, Kristen, Katolik, Protestan, Islam dan Hindhu.

b. Implementasi Sila II: Kemanusiaan yang adil dan beradab

1) Mahasiswa dalam kampus berasal dari berbagai macam latar belakang:

a) Budaya

b) Agama

c) Ras dan Suku Bangsa

2) Tidak ada pembedaan perlakuan/diskriminasi dalam kampus.

3) Semua mahasiswa diperlakukan secara adil dan sama.

c. Implementasi Sila III: Persatuan Indonesia

1) Melalui organisasi kemahasiswaan membentuk suatu jaringan perkumpulan mahasiswa dari berbagai universitas di Indonesia.

2) Hal tersebut merupakan salah satu bukti ada sikap dan upaya untuk memjalin rasa kebersamaan diantara para mahasiswa sebagai bagian dari pemuda Indonesia.

d. Implementasi Sila IV: Kerakyatan yang Dipimpin oleh Hikmat Kebijakanaan dalam Permusyawaratan/ Perwakilan

Penerapan suatu kebiasaan untuk melakukan musyawarah dan diskusi bersama terkait dengan berbagai hal merupakan cerminan yang tepat dalam implementasi sila ke-4:

1) Rapat UKM

2) Diskusi dalam kelas

3) Musyawarah penunjukkan ketua BEM

4) Pemilihan ketua Senat Mahasiswa, dan lain-lain.

e. Implementasi Sila V: Keadilan Sosial Bagi Seluruh Rakyat Indonesia

Penerapan persamaan dan saling menghargai karya orang lain:

1) Mahasiswa yang telah memenuhi syarat berhak untuk mengikuti ujian akhir semester. 
2) Setiap mahasiswa berhak memperoleh nilai sesuai dengan kemampuannya.

3) Setiap mahasiswa berupaya menghargai hasil karya orang lain dengan tidak mencontek atau membuat plagiat atas hasil karya ilmiah teman.

Makna Pancasila sebagai identitas nasional merupakan sesuatu yang amat penting dan strategis bagi eksistensi bangsa Indonesia dalam percaturan global, tanpa Pancasila sebagai identitas nasional bangsa Indonesia akan kehilangan jati diri nya sebagai bangsa besar yaitu bangsa Indonesia. Merupakan kewajiban moral untuk merealisasikan nilai-nilai tersebut di atas dalam bidang kehidupan berbangsa dan bernegara. Adapun wujud realisasinya adalah melalui pendidikan Pancasila yang juga merupakan suatu media pendidikan berkarakter bagi setiap warga negara. Jadi Pendidikan Pancasila itu sangatlah penting untuk mahasiswa dan biasa dikatakan jiwa mahasiswa itu adalah salah satu jiwa Pancasila, di dalamnya mahasiswa diajarkan banyak hal contohnya cinta kepada tanah air, ataupun yang sudah tersirat didalam sila-sila Pancasila.

\section{Pengamalan Pancasila di Lingkungan Kampus}

1. Sila Ketuhanan Yang Maha Esa

a. UKM (Unit Kegiatan Mahasiswa) yang menjadi wadah berkumpulnya mahasiswa yang berbeda latar belakang suku, ras, budaya dan agama. Misalnya saja perkumpulan mahasiswa Budha, Kristen, Katolik, Protestan, Islam dan Hindhu.

b. Jam-jam pembelajaran kuliah yang di buat tidak mengganggu dalam melaksanakan ibadah.

c. Adanya mata kuliah agama yang dijadikan mata kuliah wajib untuk mahasiswa.

d. Menghormati teman yang beribadah menurut agamanya masing-masing. e. Ikut serta dalam UKM yang nenjadi wadah berkumpulnya mahasiswa beda agama

f. Sikap tenggang rasa.

g. Menaati tata tertib kampus.

h. Beribadah tepat waktu.

2. Sila Kemanusian Yang Adil dan Beradab

a. Dalam penerimaan mahasiswa baru tidak adanya perbedaan antara yang mampu dan kurang mampu.

b. Pemberian kebebasan dalam memilih jurusan.

c. Tidak berbuat seenaknya sendiri kepada mahasiswa lain.

d. Mendapatkan hak wisuda jika sudah memenuhi semua persyaratan yang berlaku

e. Melaksanakan kewajiban untuk selalu masuk kuliah dan mengumpulkan tugas yang diberikan.

f. Saling hormat menghormati antara mahasiswa.

g. Tidak membedakan teman pergaulan.

h. Menolong orang kecelakaan.

i. Tidak membeda-bedakan teman dalam bergaul.

j. Terlibat dalam organisasi kemanusiaan.

k. Menjenguk teman yang sedang sakit.

3. Sila Persatuan Indonesia

a. Adanya komunitas antara alumni sehingga tetap ada jalinan komunikasi.

b. Adanya momen upacara bendera di harihari besar negara.

c. Tidak saling bermusuhan antara mahasiswa.

d. Saling bertukar informasi antar mahasiswa universitas lain.

e. Menjaga nama baik kampus.

f. Sikap kebersamaan, menghargai antar mahasiswa.

g. Rasa bangga sebagai warga Indonesia.

h. Hidup rukun tanpa permusuhan.

i. Ikut melaksanakan upacara bendera. 
4. Sila Kerakyatan Yang Dipimpin Oleh Hikmat Kebijaksanaan Dalam Permusyawaratan Perwakilan
a. Dalam pemilihan ketua pada setiap ukm dilakukan dengan musyawarah.
b. Menghargai pendapat teman saat ber- diskusi suatu masalah.
c. Tidak egois jika pendapatnya tidak di- terima.
d. Menjalin suasana kekeluargaan dalam mengerjakan tugas diskusi.
e. Ikut serta dalam pemilu.
f. Menyelesaikan suatu masalah dengan musyawarah.
g. Tidak memaksakan kehendak.

5. Sila Keadilan Sosial Bagi Seluruh Rakyat Indonesia
a. Membantu teman yang belum paham tentang materi kuliah.
b. Memakai baju sewajarnya sesuai tata ter- tib kampus.
c. Bekerja keras dalam mencapai cita-cita.
d. Menghargai sebuah aplikasi yang dicip- takan teman.
e. Membantu teman yang sedang tertimpa musibah.
f. Menjaga fasilitas kampus.
g. Hidup sederhana walau termasuk orang yang berkecukupan.

Mengamalkan nilai-nilai Pancasila dalam mahasiswa kita dapat melakukannya dalam beberapa jalur, yaitu jalur pendidikan dan jalur organisasi serta pengamalan secara objektif dan subjektif. Bila nilai-nilai Pancasila tertanam dengan baik di setiap individu mahasiswa, maka akan tercipta mahasiswa Pancasila yang mengerti norma-norma. Perguruan Tinggi akan menghasilkan lulusan mahasiswa yang jauh lebih baik. Oleh karena itu, pentingnya pengamalan Pancasila dalam kehidupan di kampus sangatlah amat penting demi memajukan Perguruan Tinggi agar kampus dapat menghasilkan lulusan mahasisiwa Pancasila yang dapat membangun bangsa Indonesia.

1. Dilihat dari segi jalurnya

a. Jalur pendidikan

Pendidikan memegang peranan yang sangat penting dalam pengamalan Pancasila, baik pendidikan formal (sekolahsekolah sampai dengan perguruan tinggi) maupun pendidikan nonformal (di keluarga dan lingkungan masyarakat), keduanya sangat erat kaitanya dengan kehi dupan. Dalam pendidikan formal semua tindak perbuatannya haruslah mencerminkan nilai-nilai luhur Pancasila. Dalam pendidikan keluarga pengamalan Pancasila harus ditanamkan dan dikembangkan sejak mahasiswa masih kecil, sehingga proses pendarah-dagingan nilai-nilai Pancasila dengan baik dan menuntut suasana keluarga yang mendukung. Lingkungan masyarakat juga turut menentukan sehingga harus dibina dengan sungguhsungguh supaya menjadi tempat yang subur bagi pelaksanaan pengamalan Pancasila.

Melalui pendidikan inilah mhasiswa menyerap nilai-nilai moral Pancasila. Penyerapan nilai-nilai moral Pacasila diarahkan berjalan melalui pemahaman dari pemikiran dan dan pengamalan secara pribadi. Sasaran pelaksanaan pedomaan pengamalan Pancasila adalah perorangan, keluarga, masyarakat, baik dilingkungan tempat tinggal masingmasing, maupun di lingkungan tempat menuntut ilmu.

b. Jalur organisasi

Pengamalan Pacansila harus diterapkan dalam setiap elemen kampus. Organisasi sosial pada kampus adalah wadah pemimpin-pemimpin muda dalam bidangnya masing-masing sesuai dengan keahliannya, peran dan tanggung jawabnya. 
Sehingga segala unsur-unsur dalam organisasi seperti para anggota HMJ, atau BEM, dan sebagainya harus mengikuti pedoman pengamalan Pancasila agar berkepribadian Pancasila tertanam. Sehingga organisasi dalam kampus unswagati berjalan dengan baik sesuai prosedur yang ada.

2. Pengamalan Pancasila Secara Subjektif dan Objektif

a. Pengamalan Pancasila secara Objektif

Pengamalan Pancasila yang obyektif adalah pelaksanaan dalam bentuk realisasi dalam setiap penyelengaraan kampus, baik di bidang organisasi maupun non organisasi. Semua bidang kampus unswagati terutama realisasinya dalam bentuk peraturan kampus itu tersebut antara lain sebagai berikut:

1) Tujuan, misi dan visi kampus harus memiliki beberapa arti yang tercantum dalam nilai-nilai Pancasila.

2) Aturan yang terdapat dalam kampus maupun dalam organisasi kampus harus mengandung makna nilai-nilai Pancasila.

b. Pengamalan Pancasila secara Subjektif Pengamalan Pancasila pengamalan Pancasila yang subyektif adalah pelaksanaan dalam pribadi seseorang, warga negara, individu, penduduk, penguasa, dan orang Indonesia. Pengamalan Pancasila yang subyektif ini justru lebih penting dari pengamalan yang karena pengamalan yang subyektif merupakan syarat pengamalan Pancasila yang obyektif (Notonegoro, 2004, 44).

Dengan demikian pelaksanaan Pancasila yang subyektif ini berkaitan dengan kesadaran, ketaatan, serta kesiapan individu tiap mahasiswa unswagati untuk mengamalkan Pancasila. Dalam pengertian inilah akan terwujud jika suatu keseimbangan kerohanian yang mewujudkan suatu bentuk kehidupan dimana kesadaran wajib taat aturan kampus unswagati telah berpadu menjadi kesadaran wajib moral. Sehingga dengan demikian suatu perbuatan yang tidak memenuhi wajib melaksanakan Pancasila.

Pengamalan Pancasila yang subyektif ini bilamana nilai-nilai Pancasila telah dipahami, diresapi, dan dihayati oleh seseorang mahasiswa maka orang itu telah memiliki moral Pancasila dan jika berlangsung terus menerus sehingga melekat dalam hati maka disebut dengan kepribadian Pancasila.

\section{Penutup}

Berdasarkan pembahasan yang telah dilakukan, beberapa catatan yang kiranya memerlukan pengembangan lebih lanjut adalah bahwa perspektif pendidikan Pancasila perlu dilakukan oleh perguruan tinggi dalam rangka melestarikan nilai-nilai Pancasila dan menanamkan nilai moral positif, yang terkandung di dalamnya pada generasi muda khususnya mahasiswa keberadaan mahasiswa yang mempunyai penting dan vital. Selain itu karena Pancasila sebagai dasar negara dan kepribadian bangsa Indonesia. Pancasila sebagai pandangan hidup bangsa harus dari dini dikenalkan dan diajarkan kepada masayarakat Indonesia termasuk di Perguruan Tinggi. Sebagai pembentuk intelektual yang bermoral ketuhanan dan kemanusian.

Pancasila merupakan kepribadian bangsa, harus menjadi kepribadian para generasi muda khususnya para mahasiswa yang menjadi generasi pendidikan. Melalui pendidikan Pancasila, mahasiswa akan menjadi manusia terlebih dahulu, sebelum memasuki Ipteks yang dipelajarinya. Menjadi warga negara Indonesia yang unggul dalam penguasaan Ipteks, namun tidak kehilangan jati dirinya dan tidak tercabut dari akar budaya 
bangsanya dan keimanannya. Selain itu dapat membentuk pribadi yang baik dalam bermasyarakat dan dapat menanamkan norma-norma yang baik agar dapat menajdi warga negara yang baik bagi diri sendiri, orang lain dan bangsa ini dalam berkehidupan sehari-hari.

Mengamalkan nilai-nilai Pancasila dalam mahasiswa kita dapat melakukannya dalam beberapa jalur, yaitu jalur pendidikan dan jalur organisasi serta pengamalan secra objektif dan subjektif. Bila nilai-nilai Pancasila tertanam dengan baik di setiap individu mahasiswa, maka akan tercipta mahasiswa Pancasila yang mengerti normanorma. Pengamalan Pancasila dalam kehidupan di kampus sangatlah amat penting demi memajukan Perguruan Tinggi agar kampus dapat menghasilkan lulusan mahasiswa Pancasila yang dapat membangun bangsa Indonesia.

Sesuai dengan kenyataan ini, hendaknya pendidikan Pancasila di Perguruan Tinggi harus terus dikembangkan untuk membentuk kadar yang dibutuhkan oleh negara dan masyarakat demi tercapainya tujuan umum bangsa Indonesia.

Demikian Pancasila merupakan falsafah negara kita Republik Indonesia, maka kita harus menjunjung tinggi dan mengamalkan sila-sila dari Pancasila tersebut dengan setulus hati dan penuh rasa tanggung jawab serta didasari dengan niat pada diri individu masing-masing.

\section{DAFTAR PUSTAKA}

\section{Buku}

Darmodihardjo Darji dan Shidarta, 1995, Pokok-pokok Filsafat Hukum (Apa dan Bagaimana Filsafat Hukum Indonesia), PT. Gramedia Pustaka Utama, Jakarta.

Erwin, Muhamad, 2013, Pendidikan Kewarganegaraan Republik Indonesia, Cetakan Ketiga, PT. Refika Aditama, Bandung.

Hatta, Mohammad, 2015, Politik, Kebangsaan, Ekonomi (1926-1977), Jakarta: Kompas.

Kaelan dan Achmad Zubaidi, 2007, Pendidikan Kewarganegaraan Untuk Perguruan Tinggi, Paradigma, Yogyakarta.

Kansil, C.S.T., 1986, Pengantar Ilmu Hukum dan Tata Hukum Indonesia, Balai Pustaka, Jakarta.

Munir, MBM, Umi Salamah dan Suratman, 2016, Pendidikan Pancasila, Cetakan Ketiga, Madani Media, Malang.

Notonegoro, 2004, Pancasila Dasar Filsafat Negara, Cetakan Ke-4, Panijuruan Tudjuh. Jakarta.

Wahidin, Samsul. 2015. Dasar-dasar Pendidikan Pancasila dan Pendidikan Kewarganegaraan, Cetakan Pertama, Pustaka Pelajar, Yogyakarta. 